\title{
Supplementation of Natural Antioxidants to Reduced Crude Protein Diets for Japanese Quails Exposed to Heat Stress
}

\section{-Author(s)}

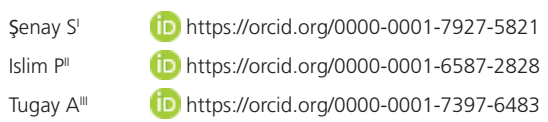

Tokat Gaziosmanpasa University, Agricultural Faculty, Department of Animal Science 60240 Tokat, Turkey

" Çukurova University, Agricultural Faculty, Department of Animal Science, 01000 Adana, Turkey.

III East Mediterranean Agricultural Research Institute Karatas Road 01321 Adana, Turkey.

\section{Mail Address}

Corresponding author e-mail address Senay Sarica

Tokat Gaziosmanpasa University, Faculty of Agriculture, Department of Animal

Science, Tokat, Turkey.

Email: senay.sarica@gop.edu.tr

\section{-Keywords}

Antioxidant enzymes, heat stress, lipid peroxidation, natural antioxidants, quails, performance.

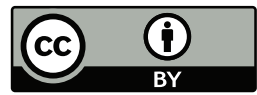

Submitted: 23/November/2017 Approved: 19/February/2018

\section{ABSTRACT}

The study aimed at comparing the effects of the supplementation of natural antioxidant sources to a reduced crude protein diet on the performance, carcass traits, blood parameters, liver antioxidant enzyme activities and meat lipid peroxidation of Japanese quails exposed to heat stress. A total of 640 14-day-old male Japanese quails were exposed to two different temperature treatments (TT): thermoneutral (TN) or heat stress (HS)and were fed five different dietary treatments (DTs). A normal-protein diet (SCP) was formulated according to the National Research Council (24\% CP). The reduced crude protein diet (RCP) was formulated to contain 3\% less protein than that of the SCP diet. Three additional diets were prepared by supplementing the RCP with $200 \mathrm{mg} / \mathrm{kg}$ of $\alpha$-tocopherol acetate (RCP+TA200), pomegranate peel extract (RCP+PPE200) or apple peel extract (RCP+APE200). HS significantly deteriorated the growth performance of quails throughout the experiment. Quails fed the SCP and RCP+PPE200 presented higher hematocrit values. Feeding the RCP+TA200 and RCP+PPE200 diets reduced the blood heterophil/lymphocyte $(H / L)$ ratio compared with the other diets. Quails fed the SCP, RCP+TA200, RCP+PPE200 and RCP+APE200 diets presented higher liver catalase and glutathione peroxidase activities, plasma uric acid level, and lower meat malondialdehyde value at 7days of age compared with those fed the RCP diet. In conclusion, the results show that the extracts of pomegranate peel and apple peel can be used as alternative natural antioxidant sources to vitamin $\mathrm{E}$ in the diets of Japanese quails exposed to heat stress and fed a reduced crude protein diet.

\section{INTRODUCTION}

Heat stress (HS) caused by increasing industrialization and environmental degradation is one of the most challenging environmental conditions affecting the poultry sector in the world (Ajakaiye et al., 2010). HS leads to the huge economic losses in the poultry industry every year as a result increased mortality and decreased growth performance (Kamboh et al., 2013; Sahin et al., 2013). During HS, birds increase their energy consumption by accelerating their metabolism to maintain optimal body temperature (Ismail et al., 2015). Lipid stores can be mobilized for energy generation to attenuate the stress response during HS. The mobilization of stored body lipids to supply the extra energy required results in lipid peroxidation and oxidative stress (Yang et al., 2010). In conclusion, HS increases malondialdehyde level and decreased the activities of ROS-scavenging enzymes and the levels of natural antioxidants such as vitamin $A, C$ and $E$ in the serum and liver of poultry (Rhoads et al., 2013; Gopi et al., 2015). HS also causes significant increases of blood heterophil to lymphocyte ratio $(H / L)$ and 
reduces haematocrit values (Lara \& Rostagno 2013; Sahin et al., 2013).

Especially in recent years, diets with low protein level have been recommended to reduce heat production in broilers under HS (Gu et al., 2008) because protein metabolism causes higher heat production compared with that of fats and carbohydrates (GonzalezEsquerra \& Leeson 2005; Gu et al., 2008). Reduced dietary protein level decreases production of uric acid (UA), which is the main end product of protein metabolism in birds (Sharifi et al., 2015a). The decrease in plasma UA levels in broilers fed a reduced-protein diet increases lipid peroxidation because plasma UA has an antioxidant role (Sharifi et al., 2015b). Plasma UA contributes to scavenge reactive oxygen species (ROS) from tissues, especially superoxide and hydroxyl radicals (Sharifi et al., 2016). Under this condition, dietary antioxidants scavenge ROS and protect the tissues against ROS (Sharifi et al., 2015a).

Moreover, it is also well known that reduced-crude protein diets intensify liver lipogenesis (Behrooj et al., 2012). It was observed that liver lipogenesis increases oxygen demand and forces the right ventricle to pump more blood to the lungs for oxygenation in broilers (Sharifi et al., 2015a,b). Subsequent overwork of the right heart ventricle, in particular, resulted in right ventricular hypertrophy, which is manifested as higher right ventricle: total ventricle ratio (Sharifi et al., 2016).

Several studies show that the dietary supplementation of natural antioxidants, such as vitamin $C$ and $E$ and $\beta$-carotene, alleviate the negative effects of lipid peroxidation caused to HS and reduced-protein diets in poultry (Sahin et al., 2009; Abidin \& Khatoon, 2013). In addition to vitamin $C$ and $E$ and $\beta$-carotene, flavonoids and polyphenols-rich foods, such as fruits, vegetables and beverages including fruit juices, wine, tea, olive leaf, pomegranate and apple peels have received much attention as natural antioxidants (Hayes et al., 2011). Recently, limited attention has been directed to other potential sources of antioxidant phytochemicals such as pomegranate peel (Kanatt et al., 2010; Ahmed et al., 2015).

Pomegranate (Punicagranatum L.) is a fruit that belongs to the Punicaceae family and is rich in beneficial phytochemicals (El-Falleh et al., 2012; Ahmed et al., 2015). The peel accounts for approximately $50 \%$ of the total fruit weight, and it is a major source of several bioactive compounds including hydrolysable tannins (Kanatt et al., 2010), flavonoids, anthocyanins and other phenolic compounds (Li et al., 2006; Ahmed et al., 2015). It was reported that pomegranate peel has higher antioxidant capacity than the pulp and the seeds due to its higher contents of total phenols, flavonoids and proanthocyanins (Li et al., 2006; Ahmed et al., 2015). The antioxidant activity of pomegranate peel or its extract were demonstrated in vitro (Gil et al., 2000; Singh et al., 2002; Li et al., 2006; Naveena et al., 2008b; Kanatt et al., 2010; Sumathy et al., 2013; Malviya et al., 2014; Zaki et al., 2015) and in vivo (Shabtay et al., 2008; Moneim 2012; Ahmed et al., 2015).

Apples also are well-known and widespread fruits of the genus Malus belonging to the family Rosaceae (Gazalli et al., 2014). Apple peels are a waste product of applesauce and canned apple manufacturing (Wolfe et al., 2003). Apple peels contain high levels of flavonols, anthocyanins, flavon-3-ols, phenolic acids and dihydrochalcones (Sekhon-Loodu et al., 2013; Wang et al., 2014). Previous studies have shown that about $80 \%$ polyphenols are concentrated in the apple peel (Leccese et al., 2009). It is reported that the apple peel contains 5-6 times higher total flavonol levels than apple pomace (Rupasinghe \& Keon 2008; SekhonLoodu etal., 2013). Sekhon-Loodu etal. (2013) reported that the fractionated polyphenol from both dried and frozen apple peel presented higher inhibition of lipid oxidation compared with $\alpha$-tocopherol acetate and buthylated hydroxytoluene (BHT). A study indicated that the ethanolic extracts of the peel and the pulp of apple showed antioxidant activity comparable with ascorbic acid in the DPPH test, and were approximately ten times more active than BHT in the lipoxygenase test (Giomaro et al., 2014).

The present study aimed at comparing the effects of the supplementation of natural antioxidant sources ( $\alpha$-tocopherol acetate, pomegranate - and applepeel extracts) to reduced-protein diets for Japanese quails exposed to normal or high temperature on their growth performance, carcass traits, blood biochemistry, liver antioxidant enzyme activities and meat lipid peroxidation.

\section{MATERIALS AND METHODS}

\section{Birdmanagement and housing}

A total of 640 one-day old male Japanese quail (Coturnix coturnix japonica) chicks purchased from a commercial hatchery (19 Mayis University Poultry Production and Marketing Plant, Samsun, Turkey) were used in the experiment. The study was conducted in accordance with animal welfare requirements at the Poultry Research Centre of Tokat Gaziosmanpasa University (2016 HADYEK-04). 
At arrival, chicks were weighed and randomly distributed into 40 wire cages (16 chicks/cage). Each cage was equipped with nipple drinkers and electrical heating system controlled by thermostats. The cages were located in the experimental poultry house in two identical rooms separated by a door. During the first 14 days of the experiment, the rooms were not separated and standard brooding temperatures were applied to both rooms with temperature gradually decreased from $32^{\circ} \mathrm{C}$ to $26^{\circ} \mathrm{C}$ by the end of the second week of age. Quails in each cage were randomly assigned to 10 experimental groups, with four replicates of 16 quails each, and according to a 2 (temperature treatments) x 5 (dietary treatments) factorial arrangement. Birds were evaluated from 14 to 35 days of age.

When birds were 14 days of age, the experimental rooms were separated, and each room, with five experimental groups each, was subjected to either thermoneutral temperature or heat stress treatments. The temperatures applied in the rooms were as follows:

1. Thermoneutral temperature room: quails were kept at 24,22 and $20^{\circ} \mathrm{C}$ until 21,28 and 35 days. Relative humidity in this room ranged from 50 to $60 \%$ during the experiment.

2. Heat stress temperature room: quails were exposed to $34^{\circ} \mathrm{C}$ for $8 \mathrm{~h} / \mathrm{d}$ (from 09:00 to $17: 00$ h) and then (from 17:00 to 09:00 h) to 24,22 , and $20^{\circ} \mathrm{C}$ until 21,28 and 35 days. Relative humidity ranged from 60 to $70 \%$ from 14 days until the end of the study. The experiment was conducted during autumn. Temperature and humidity in each room were monitored at two locations using a temperature-humidity recording system. A fluorescent lighting schedule of $23 \mathrm{~h}$ light and $1 \mathrm{~h}$ dark was used during the study, with an average light intensity of $40 \mathrm{lux} / \mathrm{m}^{2}$.

\section{Diets}

Quails submitted to both temperature regimes were fed one of five different diets in mash form until 35 days of age. The five experimental diets were as follows: standard-crude protein $\operatorname{diet}(240 \mathrm{~g}$ CP/kg; SCP), reduced-CP diet (210 CP g/kg; RCP), reduced CP diet supplemented with $200 \mathrm{mg} / \mathrm{kg}$ of $\alpha$-tocopherol acetate (vitamin $E ; R C P+T A 200$ ), pomegranate peel extract (RCP+PPE200) or apple peel extract (RCP+APE200).

Feed ingredients were ground to 1-mm particle size in preparation for chemical analysis. Prior to formulation, feed ingredients were analyzed for crude protein (CP), ether extract, starch and total sugars, according to the
Table 1 - Ingredients and calculated nutritional composition of the standard and reduced crude protein (CP) diets (fed on a dry matter basis, $\mathrm{g} / \mathrm{kg}$ ).

\begin{tabular}{|c|c|c|}
\hline Ingredients & Standard CP diet & Reduced CP diet \\
\hline Corn & 534.5 & 602.2 \\
\hline Fish Meal & 35.0 & - \\
\hline Soybean Meal & 390.0 & 350.0 \\
\hline Vegetable Oil & 17.0 & 9.2 \\
\hline Dicalcium Phosphate & 4.9 & 9.5 \\
\hline DL-Methionine & - & 0.9 \\
\hline Limestone & 11.2 & 12.0 \\
\hline L-Lysine & - & 2.5 \\
\hline L-Threonine & 1.0 & 2.5 \\
\hline Salt & 2.9 & 3.5 \\
\hline Potassium Carbonate & - & 4.2 \\
\hline Vitamin Premix ${ }^{1}$ & 2.5 & 2.5 \\
\hline Trace Mineral Premix ${ }^{2}$ & 1.0 & 1.0 \\
\hline \multicolumn{3}{|l|}{ Calculated chemical composition } \\
\hline Crude Protein, g/kg & 240 & 210 \\
\hline Metabolizable Energy, kcal/kg & 2900 & 2900 \\
\hline Calcium, g/kg & 8.0 & 8.0 \\
\hline Available Phosphorus, g/kg & 3.0 & 3.0 \\
\hline Sodium, g/ kg & 1.5 & 1.5 \\
\hline Methionine+Cystine, g/kg & 7.8 & 7.5 \\
\hline Lysine, g/kg & 13.7 & 10.0 \\
\hline Threonine, $\mathrm{g} / \mathrm{kg}$ & 10.2 & 10.2 \\
\hline
\end{tabular}

Vitamin premix/kg diet: Vitamin A, $12000 \mathrm{IU}$; vitamin $D_{3} 1500 \mathrm{IU}$; vitamin E, $50 \mathrm{mg}$; vitamin $\mathrm{K}_{3} 5 \mathrm{mg}$; vitamin $\mathrm{B}_{1} 3 \mathrm{mg}$; vitamin $\mathrm{B}_{2}, 6 \mathrm{mg}$; vitamin $\mathrm{B}_{6}, 5 \mathrm{mg}$; vitamin $\mathrm{B}_{12}, 0.03$ mg; niacin, $25 \mathrm{mg}$; Ca-D- pantothenate, $12 \mathrm{mg}$; folic acid, 1 mg; D-biotin, $0.05 \mathrm{mg}$; apo-carotenoic acid ester, $2.5 \mathrm{mg}$; choline chloride, $400 \mathrm{mg}$.

${ }^{2}$ Trace mineral premix/kg diet: Mn, 80 mg; Fe, 60 mg; Zn, 60 mg; Cu, 5 mg; Co, 0.20 $\mathrm{mg} ; \mathrm{l}, 1 \mathrm{mg} ; \mathrm{Se}, 0.15 \mathrm{mg}$.

methods of the AOAC (2007). Metabolizable energy (ME) content of the feed ingredients was calculated based on feedstuff energy values of the tables of the WPSA (1989). All diets were formulated to meet minimum nutrient requirements established by the NRC (1994). The ingredients and calculated nutritional composition of the standard and reduced CP diets are given in Table 1 . The $\alpha$-tocopherol acetate (TA) was supplied by Kartal Chemistry Ltd. (Izmit, Turkey). The vitamin and trace mineral premixes were by from Topkim-Topkapı Drug Company Ltd. (Istanbul/Turkey).

\section{Pomegranate and apple peels}

Pomegranate fruits (Punicagranatum L., Hicaznar) were supplied by the Agricultural Research Institute of West Mediterranean (Antalya, Turkey). Apple fruits (Starking variety) were supplied by a commercial firm in Tokat. The fresh fruits were manually peeled and cut using a shear. The fresh pomegranate and apple peels were immediately treated with $2 \% \mathrm{CaCl}_{2}$ in water at $55^{\circ} \mathrm{C} \pm 5$ for 10 min to inhibit the oxidation of phenolic compounds and enzyme activities. The excess 
of water was drained and the pomegranate and apple peels were collected. The pomegranate or apple peels were dried at $60^{\circ} \mathrm{C} \pm 2$ for $48 \mathrm{~h}$ in an oven with air circulation, and then ground to $0.25-\mathrm{mm}$ particle size (Sekhon-Loodu et al., 2013).

\section{Extraction of pomegranate and apple peels}

The process of ultrasonic extraction of pomegranate and apple peel powder was performed in an ultrasonic bath Elmasonic $\mathrm{S100H}$ (Elma Schmidbauer $\mathrm{GmbH}$, Singen, Germany) with a maximum capacity of $1 \mathrm{~L}$ (35 $\mathrm{kHz}, 140 \mathrm{~W}$ ). In order to obtain the pomegranate and apple peel extract, $100 \mathrm{~g}$ of dried pomegranate and apple peel powder were sonicated in $1 \mathrm{~L} 80 \%$ ethanol in water three times for $15 \mathrm{~min}$ at $10 \mathrm{~min}$ intervals between sonications (in triplicate). After the extraction, extracts were filtered using Whatman No. 1 filter papers under vacuum to remove peel debris. The extracts were concentrated to $150-200 \mathrm{~mL}$ using a rotary evaporator under reduced pressure at $37^{\circ} \mathrm{C}$ at $120 \mathrm{rpm}$ to remove solvents and filtered through Whatman No. 1 filter paper under vacuum. The remaining aqueous solutions were lyophilized at $-50^{\circ} \mathrm{C}$ and $0.028 \mathrm{mbar}$, and the crude extracts were kept in vacuum bags at $-80^{\circ} \mathrm{C}$ until use (Sekhon-Loodu et al., 2013).

The phenolic compounds of pomegranate (PPE) or apple-peel extracts (APE) are given in Table 2 .

Table 2 - Analyzed contents of phenolic compounds in APE and PPE (mg/kg extract)

\begin{tabular}{lcc}
\hline Phenolic compounds & APE & PPE \\
\hline Fumaric acid & 81703 & 1305 \\
Gentisic acid & 262 & 94 \\
Chlorogenic acid & 474 & 93 \\
Catechin & 700 & 4076 \\
4-hydroxybenzoic acid & 448 & 15 \\
Protocatechuic acid & 161 & 156 \\
Vanillic acid & 330 & 130 \\
Syringic acid & 171 & 235 \\
Rutin & 192 & 101 \\
Ellagic acid & 100 & 10201 \\
Scutellarin & - & 110 \\
Quercetin-3- $\beta$-D-glucoside & 6181 & 20 \\
Naringin & 1 & 33 \\
Diosmin & 315 & 406 \\
Morin & 143 & 107 \\
Quercetin & 360 & - \\
\hline
\end{tabular}

\section{Measurements}

\section{Performance parameters}

During the experimental period (14 to 35 days of age), the growth performance of quails was evaluated by recording body weight gain (BWG), feed intake (FI) and feed conversion ratio (FCR) on a weekly basis.
Quails were weighed using a scale with a sensitivity of $\pm 0.1 \mathrm{~g}$ at hatch and of $1 \mathrm{~g}$ thereafter. On the same day, FI was recorded and FCR was calculated weekly as the amount of feed consumed per unit of BWG. Mortality was recorded daily throughout the experiment.

\section{Blood analysis and plasma biochemistry parameters}

At 35 days of age, 12 quails from each treatment group were randomly selected and bled from the brachial vein. The bleeding procedure was limited to 1 min or less to minimize the effects of handling stress. Quails were anesthetized with sodium pentobarbital injection (100 mg/kg) before slaughter.

In order to estimate heterophil to lymphocyte ratio $(\mathrm{H} / \mathrm{L})$, blood samples were collected in tubes containing EDTA and smeared on a glass slide. After drying, smears were stained with May-Grunwald and Giemsa stains (Gross \& Siegel, 1983). One-hundred leukocytes were counted on one slide per quail using a light microscope at $\times 1,000$ magnification. The $\mathrm{H} / \mathrm{L}$ ratio was calculated by dividing the number of heterophils by the number of lymphocytes.

Blood for hematocrit determination was collected in heparinized capillary tubes and centrifuged in a microhematocrit centrifuge for $7 \mathrm{~min}$ at $11500 \mathrm{rpm}$.

At the end of this trial ( $35 \mathrm{~d}$ ), blood samples from the brachial veins of 12 slaughtered quails were collected in tubes containing EDTA. Tubes were centrifuged for $15 \mathrm{~min}$ at $3000 \mathrm{rpm}$ to separate the plasma, which was stored in Eppendorf tubes at $-20^{\circ} \mathrm{C}$ till analyses. Plasma samples were analyzed for total protein and uric acid levels using autoanalyser test kits (Audit Diagnostics, Ireland) and Audit Autoanalyser (Autolab, AMS Srl, The Netherlands), respectively, as described by the manufacturers. These plasma biochemistry parameters were determined at the Biochemistry Department, Faculty of Medicine, Tokat Gaziosmanpasa University.

\section{Carcass parameters}

On d 35, 12 quails whose BWs were similar to the group average were selected from each treatment groups and slaughtered by severing the jugular vein to determine preslaughter $\mathrm{BW}$; the relative weights of the heart, liver and lung; hot and cold carcass yields; and breast and thigh meat yields. Carcasses were immediately plucked, processed (removal of head and feet), eviscerated (removal of gastrointestinal tract), weighed, and then chilled overnight in a refrigerator $\left(+4^{\circ} \mathrm{C}\right)$. Measurements included hot and cold carcass yields, breast and thigh meat yields, the relative weight of heart, liver and lung. The relative weight of heart, liver and lung and hot and cold carcass yields 
were calculated as a percentage of preslaughter BW. The heart was removed and the right ventricle was dissected from the left ventricle and septum. The right and left ventricles were separately weighed and the ratio of right ventricular (RV) weight to total ventricular (TV) weight (RV/TV) was determined.

\section{Liver antioxidant enzyme activities}

The livers of the 12 quails slaughtered per treatment were immediately excised and thoroughly washed in ice-cold potassium phosphate buffer $(\mathrm{pH} \mathrm{7.4)}$ to remove the blood on the livers. Approximately $1 \mathrm{~g}$ liver was used to prepare the whole liver homogenate $(\mathrm{WLH})$. The liver pieces were diluted 1:10 (wt/vol) with $50 \mathrm{mM}$ an ice-cold Tris-HCl buffer (pH 7.4) and homogenized using an Ultra-Turrax homogenizer (Tekmar Co., Cincinnati, OH, USA). The homogenate was centrifuged for $30 \mathrm{~min}$ at $3500 \mathrm{rpm}$ at $4^{\circ} \mathrm{C}$ and the supernatant was collected to determine of liver antioxidant enzyme activities.

Liver glutathione peroxidase (GPx) activity was assessed by degradation of hydrogen peroxide $\left(\mathrm{H}_{2} \mathrm{O}_{2}\right)$ in the presence of reduced glutathione, according to the method of Paglia \& Valentine (1967) and expressed as units/mg protein. Catalase (CAT) activity was measured by the rate of $\mathrm{H}_{2} \mathrm{O}_{2}$ disappearance according to Aebi (1984) and expressed as units/mg protein. Liver superoxide dismutase (SOD) activity was determined following the xanthine oxidase method described by Sun et al. (1988) and expressed as units/mg protein. Protein concentrations of the WLH were determined by the method of Lowry et al. (1951).

\section{Malondialdehyde assay}

The breast and thigh meats of 12 quails slaughtered per treatment were used to determine the malondialdehyde levels of meats stored in refrigerator for 0 and 7 days. Malondialdehyde, the compound used as an index of lipid peroxidation, was determined by a selective third-order derivative spectrophotometric method (Botsoglou et al., 2002). Samples were thoroughly homogenized (Polytron homogenizer, PCU, Littau/Lucerne, Switzerland) in the presence of $8 \mathrm{~mL}$ of aqueous trichloroacetic acid $(50 \mathrm{~g} / \mathrm{L})$ and $5 \mathrm{~mL}$ of butylated hydroxytoluene in hexane $(8 \mathrm{~g} / \mathrm{L})$, and the mixture was centrifuged. The top layer was discarded and a $2.5 \mathrm{~mL}$ aliquot from the bottom layer was mixed with $1.5 \mathrm{~mL}$ of aqueous 2-thiobarbituric acid (8 $\mathrm{g} / \mathrm{L})$ and further incubated at $70^{\circ} \mathrm{C}$ for $30 \mathrm{~min}$. Following incubation, the mixture was cooled to room temperature and submitted to conventional spectrophotometry (Shimadzu, Model UV-160A, Tokyo, Japan) at $530 \mathrm{~nm}$. Malondial- dehyde values were calculated by data of the computed least-squares fit of the standard calibration curve prepared using 1,1,3,3- tetraethoxypropane.

\section{Statistical analysis}

Data were analyzed according to a $2 \times 5$ factorial arrangement by two-way analysis of variance using the General Linear Model procedure of SPSS statistic package (SPSSWIN 2007). Dietary and temperature treatments and their interactions were evaluated. Significant differences among treatment means were separated using Duncan's multiple range test (Duncan 1955). Data were assumed to be statistically significant when $p<0.05$. Chi-square analysis was performed for mortality rates.

\section{RESULTS AND DISCUSSION}

\section{Performance Parameters}

Average BW of quails at 14 days of age was $54 \pm 0.306 \mathrm{~g}$ and did not differ statistically among the treatment groups. Weekly average body weight (BWs), body weight gain (BWG), feed intake ( $\mathrm{FI}$ ) and feed conversion ratio (FCR) of 14- to 35 -d-old quails are shown in Table 3.

Table 3 shows that the supplementation of natural antioxidant sources ( $\alpha$-tocopherol acetate and pomegranate - and apple-peel extracts) to the reduced $C P$ diet did not significantly affect quail BW, BWG, FI and FCR. As shown in Table 3, quail BWs at $21(p<0.05), 28(p<0.01)$ and $35(p<0.05)$ days of age were reduced only when birds were maintained in HS. This result is in agreement with the findings of Bonnet et al. (1997) who reported that the BW of male broilers from 4 to 6 wks of age was decreased by HS compared with those maintained at TN temperatures. The reduced BW due to HS may be due lower amounts of nutrients available for growth because HS reduces nutrient digestibility (Hai et al., 2000).

HS reduced quail BWG during the period of 14 to 35 days $(p<0.05)$ compared with that of quails reared at TN. This result is consistent with those of GonzalezEsquerra \& Leeson (2005), Faria Filho et al. (2007) and $\mathrm{Gu}$ et al. (2008), who reported that HS significantly decreased the BWG of broilers from 21 to 42 days of age. This may be explained by the reduction of the digestibility of protein, lipid and starch as result of HS (Zuprizal et al., 1993; Bonnet et al., 1997; Faria Filho et al., 2007). Moreover, Hai et al. (2000) showed that the passage of the digesta from the crop or small intestine was suppressed by $\mathrm{HS}\left(32^{\circ} \mathrm{C}\right)$ and that the activities 
Table 3 - Effects of the experimental treatments on the body weight, body weight gain, feed intake and feed conversion ratio of quails reared under thermoneutral(TN) or heat stress (HS) conditions

\begin{tabular}{|c|c|c|c|c|c|c|c|c|}
\hline \multirow{2}{*}{ DT } & \multirow{2}{*}{$\mathrm{TT}$} & \multicolumn{4}{|c|}{ BW (g) } & \multirow{2}{*}{$\frac{B W G(g)}{14-35 d}$} & \multirow{2}{*}{$\begin{array}{c}\mathrm{FI}(\mathrm{g}) \\
14-35 \mathrm{~d}\end{array}$} & \multirow{2}{*}{$\frac{F C R(g: g)}{14-35 d}$} \\
\hline & & $14 d$ & $21 \mathrm{~d}$ & $28 d$ & $35 d$ & & & \\
\hline \multirow{2}{*}{ SCP } & TN & 54 & 107 & 156 & 192 & 138 & 540 & 3.90 \\
\hline & $\mathrm{HS}$ & 55 & 105 & 153 & 192 & 137 & 507 & 3.70 \\
\hline \multirow{2}{*}{$\mathrm{RCP}$} & TN & 54 & 106 & 155 & 194 & 141 & 537 & 3.82 \\
\hline & $\mathrm{HS}$ & 54 & 105 & 149 & 188 & 134 & 551 & 4.13 \\
\hline \multirow{2}{*}{$R C P+T A 200$} & TN & 54 & 107 & 156 & 194 & 140 & 531 & 3.78 \\
\hline & HS & 54 & 103 & 150 & 190 & 136 & 579 & 4.27 \\
\hline \multirow{2}{*}{ RCP+PPE200 } & TN & 53 & 107 & 157 & 196 & 143 & 541 & 3.80 \\
\hline & HS & 54 & 105 & 148 & 187 & 133 & 553 & 4.17 \\
\hline \multirow{2}{*}{ RCP+APE200 } & TN & 54 & 106 & 153 & 195 & 141 & 511 & 3.63 \\
\hline & HS & 54 & 105 & 148 & 188 & 134 & 549 & 4.10 \\
\hline \multirow{5}{*}{ DTs } & SCP & 54 & 106 & 154 & 192 & 138 & 523 & 3.80 \\
\hline & RCP & 54 & 106 & 152 & 191 & 137 & 544 & 3.97 \\
\hline & $\mathrm{RCP}+\mathrm{TA} 200$ & 54 & 105 & 153 & 192 & 138 & 555 & 4.02 \\
\hline & RCP+PPE200 & 54 & 106 & 152 & 192 & 138 & 547 & 3.99 \\
\hline & $R C P+A P E 200$ & 54 & 105 & 151 & 191 & 137 & 530 & 3.87 \\
\hline SEM & & 0.306 & 1.356 & 2.008 & 2.948 & 2.871 & 17.907 & 0.111 \\
\hline \multirow{2}{*}{ TTs } & $\mathrm{TN}^{1}$ & 53 & $106^{\mathrm{a}}$ & $155^{a}$ & $194^{a}$ & $141^{\mathrm{a}}$ & $532^{b}$ & $3.79^{b}$ \\
\hline & $\mathrm{HS}^{2}$ & 54 & $104^{b}$ & $150^{b}$ & $189^{b}$ & $135^{b}$ & $548^{a}$ & $4.07^{a}$ \\
\hline SEM & & 0.194 & 0.857 & 1.270 & 1.864 & 1.816 & 6.395 & 0.070 \\
\hline \multicolumn{9}{|l|}{$p$-value } \\
\hline DT & & & NS & NS & NS & NS & NS & NS \\
\hline $\mathrm{TT}$ & & & * & $\star *$ & * & * & * & ** \\
\hline DT $x$ TT & & & NS & NS & NS & NS & NS & NS \\
\hline
\end{tabular}

${ }^{a-b}$ Values in the same column not sharing a common superscript significantly differ ( $\left.{ }^{*} p<0.05 ;^{* *} p<0.01\right)$.

DT: dietary treatments; TT: temperature treatments; ${ }^{1} \mathrm{TN}$ : thermoneutral temperature; ${ }^{2} \mathrm{HS}$ : heat stress.

SCP: Diet with standard crude protein level (24\% crude protein, $2900 \mathrm{kcalME} / \mathrm{kg}$ ); RCP: Reduced crude protein diet (21\% crude protein, 2900 kcalME/kg); RCP+TA200:RCP supplemented with $200 \mathrm{mg} \alpha$-tocopherol acetate/kg; RCP+PPE200:RCP supplemented with $200 \mathrm{mg}$ pomegranate peel extract/kg; RCP+APE200:RCP supplemented with 200 mg apple peel extract $/ \mathrm{kg}$

of three digestive enzymes (trypsin, chymotrypsin and amylase) and nutrient digestibility were reduced at HS.

Furthermore, in the present study, no significant BWG differences were determined in quails fed the SCP and RCP diets at both temperatures (TN and HS). This finding is in agreement with the result of Aydilek et al. (2012), who reported that there are no significant differences in the BWG of broilers fed diets with $18 \%$ or $23 \% \mathrm{CP}$ and maintained at $22^{\circ} \mathrm{C}$ or $30^{\circ} \mathrm{C}$. The results suggest that the reduced $C P$ diet can support the same BWG as the standard CP diet when highly-digestible ingredients are used and digestible amino acids levels were well balanced in the diets (Widyaratne \& Drew, 2011). On the other hand, our BWG results are different from the finding of Temim et al. (1999), who reported that feeding a high CP diet (20\%vs. 25\%) significantly increased the BWG of broilers from 28 to 42 days of age.

Quails submitted to HS presented higher Fl during the period of 14 to 35 days $(p<0.05)$ with those at TN. This may be due to the higher energy requirement for maintenance of broilers fed the low CP diets (Nieto et al., 1997; Furlan et al., 2004). The lack of influence of $\mathrm{CP}$ on $\mathrm{Fl}$ observed in the present study is in agreement with the results of Gonzalez-Esquerra \& Leeson (2005) and Aydilek et al., 2012), who reported that broiler FI was not influenced by dietary CP content $(18 \%$ and $23 \%$ ).

Moreover, FCR was not influenced by the dietary treatments; however, quails submitted to HS presented significantly higher FCR from 14 to 35 days compared with those reared at TN $(p<0.01)$. Faria Filho et al. (2007) also reported that HS significantly deteriorated the FCR of broilers between 21 and 42 days of age compared with those reared at TN. This may be due to the reduction of trypsin, chymotrypsin and amylase activities caused by HS, resulting in reduced digestibility and absorption of nutrients, such as protein, carbohydrate and lipids. In the present experiment, broilers fed the low CP diet supplemented with synthetic amino presented similar FCR as those fed the standard CP protein diet, independently of HS. Aydilek et al. (2012) also reported that broilers fed diets with two CP levels and reared under TN and HS 
presented the same FCR. Moreover, our FCR results are consistent with the studies of Sahin et al. (2002) and Habibian et al. (2016), who did not find any influence of vitamin $\mathrm{E}$ supplementation on the FCR of broilers reared at TN or HS. On the other hand, Sahin \& Kucuk (2001) demonstrated improvements in FCR in heatstressed Japanese quail fed a diet supplemented with $250 \mathrm{mg} / \mathrm{kg}$ vitamin $\mathrm{E}$.

\section{Hematocrit value and heterophil/lympho- cyte ratio}

The effects of experimental treatments on hematocrit value and blood heterophil/lymphocyte $(\mathrm{H} / \mathrm{L})$ ratio of quails reared under TN and HS were summarized in Table 4.

As shown in Table 4, quails exposed to HS presented lower hematocrit value compared with those reared at TN $(p<0.01)$.In addition, the SCP and RCP+PPE200 diets increased the hematocrit value of quails $(p<0.05)$. The heterophil/lymphocyte ratio on day 35 of quails exposed to HS was increased compared with those reared in TN $(p<0.05)$. Feeding the RCP+TA200 and RCP+PPE200 diets decreased the heterophil/ lymphocyte ratio of blood in quails compared to those of quails fed the SCP, RCP and RCP+APE200 diets $(p<0.05)$. This finding is in agreement with the results of Ipek et al. (2007), who reported that dietary supplementation of vitamin $\mathrm{C}$ and $\mathrm{E}$ alone or in combination reduced the $\mathrm{H} / \mathrm{L}$ ratio of heat-stressed Japanese quails. In addition, Prieto and Campo (2010) indicated that dietary allicin or capsaicin supplementation to heat-stressed white leghorn chickens decreased their $\mathrm{H} / \mathrm{L}$ ratio compared with those fed a diet with no additives, suggesting that antioxidants compounds, such as allicin and capsaicin, may alleviate the oxidative deterioration caused by HS. Both Ipek et al. (2007) and Mahmoud et al. (2014) reported that dietary ascorbic acid (at $0.5 \mathrm{~g} / \mathrm{kg}$ ) reduced $\mathrm{H} / \mathrm{L}$ ratio and plasma corticosterone level of Japanese quails and broilers under HS, respectively.

The reduced $H / L$ ratio obtained in quails fed the diets supplemented with vitamin E and pomegranate extract in our study may be due to their inhibitory effect on glucocorticoid synthesis in birds (Sharifi et al., 2016), which reduces plasma corticosterone level and consequently increasing lymphocyte numbers and reducing $\mathrm{H} / \mathrm{L}$ ratio (Noyan, 1993).

\section{Liver antioxidant enzyme activities}

The effects of experimental treatments on the liver antioxidant enzyme activities of quails reared under TN and HS are summarized in Table 5.
Table 4 - Effects of experimental treatments on hematocrit value and heterophil/lymphocyte $(\mathrm{H} / \mathrm{L})$ ratio of quails reared under thermoneutral (TN) or heat stress (HS) conditions.

\begin{tabular}{|c|c|c|c|}
\hline DTs & TTS & Hematocrit value & $\mathrm{H} / \mathrm{L}$ ratio \\
\hline \multirow{2}{*}{ SCP } & TN & 51.3 & 0.350 \\
\hline & $\mathrm{HS}$ & 48.7 & 0.460 \\
\hline \multirow{2}{*}{$\mathrm{RCP}$} & TN & 49.9 & 0.450 \\
\hline & $\mathrm{HS}$ & 46.1 & 0.600 \\
\hline \multirow{2}{*}{$R C P+T A 200$} & TN & 49.2 & 0.340 \\
\hline & $\mathrm{HS}$ & 47.4 & 0.390 \\
\hline \multirow{2}{*}{ RCP+PPE200 } & TN & 51.7 & 0.200 \\
\hline & $\mathrm{HS}$ & 49.0 & 0.440 \\
\hline \multirow{2}{*}{ RCP+APE200 } & TN & 49.0 & 0.520 \\
\hline & $\mathrm{HS}$ & 48.1 & 0.510 \\
\hline \multirow{5}{*}{ DTs } & SCP & $50.0^{a}$ & $0.410^{b}$ \\
\hline & $\mathrm{RCP}$ & $48.0^{b}$ & $0.530^{a}$ \\
\hline & $\mathrm{RCP}+\mathrm{TA} 200$ & $48.4^{b}$ & $0.370^{c}$ \\
\hline & $R C P+P P E 200$ & $50.4^{a}$ & $0.320^{c}$ \\
\hline & RCP+APE200 & $48.6^{b}$ & $0.520^{a}$ \\
\hline SEM & & 1.045 & 0.060 \\
\hline \multirow{2}{*}{ TTS } & $\mathrm{TN}^{1}$ & $50.2^{a}$ & $0.370^{b}$ \\
\hline & $\mathrm{HS}^{2}$ & $47.9^{b}$ & $0.480^{a}$ \\
\hline SEM & & 0.661 & 0.038 \\
\hline \multicolumn{4}{|l|}{$p$ value } \\
\hline DTs & & * & * \\
\hline TTS & & ** & * \\
\hline DTs $x$ TTs & & NS & NS \\
\hline
\end{tabular}

a-b Values in the same column not sharing a common superscript significantly differ $\left({ }^{*} p<0.05 ;{ }^{* *} p<0.01\right)$.

DT: dietary treatments; TT: temperature treatments; 'TN: thermoneutral temperature; ${ }^{2} \mathrm{HS}$ : heat stress.

SCP: Diet with standard crude protein level (24\% crude protein, $2900 \mathrm{kcal} \mathrm{ME} / \mathrm{kg}$ ); RCP: Reduced crude protein diet ( $21 \%$ crude protein, $2900 \mathrm{kcal} \mathrm{ME} / \mathrm{kg}$ ); RCP+TA200: RCP supplemented with $200 \mathrm{mg} \alpha$-tocopherol acetate/kg; RCP+PPE200: RCP supplemented with $200 \mathrm{mg}$ pomegranate peel extract/kg; RCP+APE200: RCP supplemented with $200 \mathrm{mg}$ apple peel extract/kg.

As indicated in Table 5, quails under HS presented lower liver catalase activity compared with those reared under TN $(p<0.05)$. This result is consistent with the findings of Jena et al. (2013) and Ayazi (2014), who reported that HS reduced liver catalase activity of broilers. The superoxide radicals formed during HS prevent the activity of catalase (Halici et al., 2012). The reduced catalase activity observed in quails submitted to $\mathrm{HS}$ indicates that the exposure to HS impaired the birds' ability to detoxify $\mathrm{H}_{2} \mathrm{O}_{2}$ via catalase and hydrogen peroxide $\left(\mathrm{H}_{2} \mathrm{O}_{2}\right)$ accumulation (Halici et al.,2012). Catalase reacts with the generated $\mathrm{H}_{2} \mathrm{O}_{2}$ resulting in molecular oxygen and water, protecting cells against hydrogen peroxide toxicity and lipid peroxidation (Jena et al., 2013).

Higher liver catalase activity was observed especially when the RCP+TA200 and PRD+PPE200 diets were fed compared with the other diets $(p<0.05)$. This is in agreement with the findings of Jena et al. (2013), who 
Table 5 - The effects of experimental treatments on the liver antioxidant enzyme activities of quails reared under thermoneutral (TN) or heat stress (HS) conditions.

\begin{tabular}{|c|c|c|c|c|}
\hline DTs & TTs & Catalase & SOD & GPX \\
\hline \multirow{2}{*}{ SCP } & TN & 0.426 & 0.107 & 0.983 \\
\hline & HS & 0.164 & 0.105 & 1.09 \\
\hline \multirow{2}{*}{$\mathrm{RCP}$} & TN & 0.281 & 0.109 & 1.19 \\
\hline & HS & 0.210 & 0.073 & 0.398 \\
\hline \multirow{2}{*}{$\mathrm{RCP}+\mathrm{TA2} 200$} & TN & 0.424 & 0.117 & 1.94 \\
\hline & HS & 0.418 & 0.113 & 0.681 \\
\hline \multirow{2}{*}{$R C P+P P S 200$} & TN & 0.395 & 0.111 & 1.36 \\
\hline & HS & 0.286 & 0.096 & 1.06 \\
\hline \multirow{2}{*}{$R C P+A P E 200$} & TN & 0.291 & 0.111 & 0.692 \\
\hline & HS & 0.223 & 0.074 & 1.00 \\
\hline \multirow{5}{*}{ DTs } & SCP & $0.295^{c}$ & 0.106 & $1.05^{\mathrm{a}}$ \\
\hline & RCP & $0.246^{e}$ & 0.091 & $0.793^{c}$ \\
\hline & $\mathrm{RCP}+\mathrm{TA} 200$ & $0.421^{a}$ & 0.115 & $1.31^{\mathrm{a}}$ \\
\hline & RCP+PPE200 & $0.341^{b}$ & 0.104 & $1.17^{\mathrm{a}}$ \\
\hline & $R C P+A P E 200$ & $0.257^{d}$ & 0.093 & $0.875^{b}$ \\
\hline SEM & & 0.066 & 0.008 & 0.188 \\
\hline \multirow{2}{*}{ TTS } & $\mathrm{TN}^{1}$ & $0.363^{\mathrm{a}}$ & 0.111 & $1.330^{\mathrm{a}}$ \\
\hline & $\mathrm{HS}^{2}$ & $0.260^{b}$ & 0.092 & $0.751^{b}$ \\
\hline SEM & & 0.042 & 0.005 & 0.119 \\
\hline \multicolumn{5}{|l|}{$p$ value } \\
\hline DTs & & * & NS & * \\
\hline TTS & & * & NS & * \\
\hline DTs $x$ TTS & & NS & NS & NS \\
\hline
\end{tabular}

a-c Values in the same column not sharing a common superscript significantly differ $\left({ }^{*} p<0.05\right)$.

DT: dietary treatments; $\mathrm{TT}$ : temperature treatments; ${ }^{1} \mathrm{TN}$ : thermoneutral temperature; ${ }^{2} \mathrm{HS}$ : heat stress. SOD: Superoxide dismutase; GPX: Glutathione peroxidase

SCP: Diet with standard crude protein level (24\% crude protein, $2900 \mathrm{kcal} \mathrm{ME} / \mathrm{kg}$ ); RCP: Reduced crude protein diet (21\% crude protein, $2900 \mathrm{kcal} M E / \mathrm{kg}) ; \mathrm{RCP}+\mathrm{TA} 200$ : RCP supplemented with $200 \mathrm{mg} \alpha$-tocopherol acetate/kg; RCP+PPE200: RCP supplemented with $200 \mathrm{mg}$ pomegranate peel extract/kg; RCP+APE200: RCP supplemented with $200 \mathrm{mg}$ apple peel extract/kg.

observed that catalase activity in the erythrocytes of broiler breeders at the $8^{\text {th }}$ week of their experiment was significantly higher with a diet supplemented with vitamin $\mathrm{E}$ than with the control diet. In addition, the obtained result indicates that vitamin $\mathrm{E}$ and pomegranate peel extract exert their antioxidant effect in quails under HS by neutralizing hydrogen peroxide radicals donating one electron to free radical chains (Avanzo et al., 2001). On the other hand, Halici et al. (2012) found that dietary vitamin E supplementation reduced the activity of catalase in the muscle tissue in heat-stressed Japanese quails.

No effects of DT or TT on liver superoxide dismutase activity of liver in quails was detected ( $p>0.05)$.

Lower glutathione liver peroxidase (GPx) activity was observed in $\mathrm{HS}$ quails compared with those reared under TN $(p<0.05)$. Moreover, higher GPx activity of liver was detected in quails fed the SCP, RCP+TA200 and RCP+PPE200 diets compared to the RCP and RCP+APE200 diets $(p<0.05)$, and those fed the RCP+APE200 diet presented significantly higher GPx activity compared to those fed the RCP diet $(p<0.05)$. This finding is in agreement with the results of Halici et al. (2012) and Ayazi (2014), who found that vitamin E supplementation to the diet of heat-stressed quails increased their liver GPx activity.

Genena \& Agamy (2017) reported fed pomegranate peel promoted a significant increase in plasma catalase (CAT) and GPx activities in hyperlipidemic rats. The antioxidant properties of pomegranate peel are possibly due to its content of potent tannins and anthocyanins that scavenge a wide spectrum of free radicals (Gil et al., 2000; Aviram et al., 2000). Pomegranate peel extract may be an important factor in protecting the tissue against oxidative injury by increasing the freeradical scavenging activity of CAT and GPx (Moneim, 2012). Moneim (2012) showed that pomegranate peel extract significantly increased brain CAT activity in rats. Pomegranate can counteract oxidative stress effects through its antioxidant properties (Dkhil et al., 2013). The results obtained in the present study with pomegranate peel extract may be attributed to its phenolic compounds and linolenic acid content. The antioxidant activity of phenolic compounds and linolenic acid are mainly due to their redox properties, which allow them to act as reducing agents, hydrogen donors, singlet oxygen quenchers and metal chelators (Wei et al., 2015). Wei et al. (2015) reported that pomegranate administration to rats induced by carbon tetrachloride significantly enhanced their liver GPx activity.

\section{Plasma total protein and uric acid levels}

The effects of experimental treatments on plasma total protein and uric acid levels in quails reared under $\mathrm{TN}$ and HS were given in Table 6 .

As shown in Table 6, both DT and TT influenced plasma uric acid level $(p<0.05)$. Quails exposed to HS presented lower plasma uric acid levels compared to those reared at TN $(p<0.05)$. According to Imik et al. (2013), increasing concentrations of plasma corticosterone during HS increased the rate of uric acid excretion. The uric acid level results of the present study are in agreement with the findings of Adams (1968) and Siegel \& Van Kampen (1984), who showed that uric acid levels were reduced in broilers submitted to HS.

The SCP, RCP+TA200, RCP+PPE200 and $R C P+A P E 200$ diets increased plasma uric acid levels 


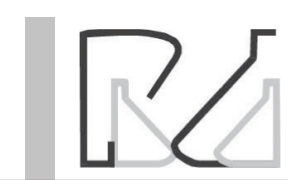

Table 6 - Effects of experimental treatments on plasma total protein and uric acid levels in quails reared under TN and HS.

\begin{tabular}{|c|c|c|c|}
\hline DTs & TTS & Uric Acid & Total Protein \\
\hline \multirow{2}{*}{ SCP } & $\mathrm{TN}$ & 5.79 & 2.73 \\
\hline & $\mathrm{HS}$ & 5.37 & 2.93 \\
\hline \multirow{2}{*}{$\mathrm{RCP}$} & $\mathrm{TN}$ & 4.09 & 2.67 \\
\hline & HS & 3.11 & 2.20 \\
\hline \multirow{2}{*}{$\mathrm{RCP}+\mathrm{TA} 200$} & TN & 5.61 & 2.68 \\
\hline & $\mathrm{HS}$ & 4.36 & 2.64 \\
\hline \multirow{2}{*}{ RCP+PPE200 } & $\mathrm{TN}$ & 4.88 & 2.96 \\
\hline & $\mathrm{HS}$ & 4.56 & 2.29 \\
\hline \multirow{2}{*}{$R C P+A P E 200$} & $\mathrm{TN}$ & 4.76 & 2.62 \\
\hline & $\mathrm{HS}$ & 3.52 & 2.49 \\
\hline \multirow{5}{*}{ DTs } & SCP & $5.58^{a}$ & 2.83 \\
\hline & $\mathrm{RCP}$ & $3.60^{c}$ & 2.43 \\
\hline & $\mathrm{RCP}+\mathrm{TA} 200$ & $4.98^{\mathrm{ab}}$ & 2.66 \\
\hline & $R C P+P P E 200$ & $4.72^{\mathrm{ab}}$ & 2.63 \\
\hline & $R C P+A P E 200$ & $4.14^{b}$ & 2.56 \\
\hline SEM & & 0.363 & 0.139 \\
\hline \multirow{2}{*}{ TTs } & $\mathrm{TN}^{1}$ & $5.02^{a}$ & 2.73 \\
\hline & $\mathrm{HS}^{2}$ & $4.18^{b}$ & 2.51 \\
\hline SEM & & 0.230 & 0.089 \\
\hline \multicolumn{4}{|l|}{$p$ value } \\
\hline DTs & & * & NS \\
\hline TTS & & * & NS \\
\hline DTs $x$ TTs & & NS & NS \\
\hline
\end{tabular}

${ }^{a-c}$ Values in the same column not sharing a common superscript significantly differ $\left({ }^{*} p<0.05\right)$.

DT: dietary treatments; $\mathrm{TT}$ : temperature treatments; ${ }^{1} \mathrm{TN}$ : thermoneutral temperature; ${ }^{2} \mathrm{HS}$ : heat stress.

SCP: Diet with standard crude protein level (24\% crude protein, $2900 \mathrm{kcal} \mathrm{ME} / \mathrm{kg}$ ); RCP: Reduced crude protein diet ( $21 \%$ crude protein, $2900 \mathrm{kcal} \mathrm{ME} / \mathrm{kg}) ; \mathrm{RCP}+\mathrm{TA} 200$ : RCP supplemented with $200 \mathrm{mg} \alpha$-tocopherol acetate/kg; RCP+PPE200: RCP supplemented with $200 \mathrm{mg}$ pomegranate peel extract/kg; RCP+APE200: RCP supplemented with $200 \mathrm{mg}$ apple peel extract/kg.

of quail compared with the RCP diet $(p<0.05)$. This result is consistent with the findings of Imik et al. (2013), who reported that the plasma uric acid levels of heat-stressed broilers were enhanced by the dietary supplementation of vitamin $C$ or $\alpha$-lipoic acid. On the other hand, Sahin et al. (2002) showed that, during HS, increasing concentrations of ACTH enhanced serum uric acid levels, whereas vitamin E supplementation reduced uric acid levels. Likewise, Yassein et al. (2015) showed that the dietary supplementation of pomegranate peel powder to quail diets significantly decreased plasma uric acid level.

Plasma total protein levels of quails in the present study were not affected neither by DTs nor TTs. This is consistent with the findings of Sahin et al. (2002) and Imik et al. (2013), who demonstrated that dietary supplementation of different antioxidants (vitamin C, $\alpha$-lipoic acid or vitamin E) did influence plasma total protein levels.

\section{Supplementation of Natural Antioxidants to Reduced Crude Protein Diets for Japanese Quails Exposed to Heat Stress}

\subsection{Carcass traits}

The effects of the experimental treatments on the carcass traits of quails are summarized in Table 7.

As shown in Table 7, heat-stressed quails presented significantly lower liver relative weight compared to those reared under TN ( $p<0.05)$. Tawfeek et al. (2014) also showed lower liver yield in broilers submitted to HS, and Konca et al. (2009) and Tawfeek et al. (2014), who reported that the dietary antioxidant supplementation did not have any significant effect on the liver relative weight of broilers.

A significant interaction between DTs and TTs was determined for lung relative weight of the evaluated quails $(p<0.05)$. The lung relative weights of the quails fed the SCP, RCP and RCP+APE diets were not significantly affected by TTS; however, the quails fed the RCP+TA200 and RCP+PPE200 diets presented significantly lower lung relative weights when submitted to HS compared with TN $(p<0.05)$. The relative weights of lung of quails exposed to TN were not significantly influenced by DTs, but in those submitted to HS, lung relative weights were significantly reduced by all the evaluated diets compared with the SCP diet $(p<0.05)$.

HS significantly decreased the hot and cold carcass yields of quails compared to those of quails exposed to TN $(p<0.05)$. This result is in agreement with the findings of Tawfeek et al. (2014), who reported reduced carcass yield in heat-stressed broilers compared with those in TN conditions. This reduction may be due to impaired protein synthesis by HS (Temim et al., 2000). Conversely, Habibian et al. (2016) reported that the carcass yield of broilers was not influenced by environmental temperature.

There is a significant interaction between DTs and TTs for hot and cold carcass yields in the present experiment $(p<0.05)$. The hot and cold carcass yields of quails exposed to TN were significantly increased by the SCP, RCP+TA200 and RCP+PPE200 diets compared to those of quails fed the RCP and RCP+APE200 diets $(p<0.05)$. On the other hand, the hot and cold carcass yields of quails exposed to HS were not significantly affected by the DTs.

The ratio of the right ventricular weight to the total ventricular weight (RV/TV ratio) was significantly higher in HS compared with TN $(p<0.05)$. It is evident that quails exposed to HS are in a pre-ascitic condition. In contrast to our finding, some studies indicated that the observed significant increase of the RV/TV ratio was due to a reduction in dietary CP (Behrooj et al., 2012; Sharifi et al., 2015a,b). In addition, Sharifi et al. $(2015 a, b)$ also reported that the dietary 
Table 7 - Effects of experimental treatments on carcass traits of quails reared under thermoneutral (TN) or heat stress (HS) conditions.

\begin{tabular}{|c|c|c|c|c|c|c|c|c|c|}
\hline DTs & TTS & PSBW, $g$ & Liver, \% & Lung, \% & $\begin{array}{l}\text { Hot Carcass } \\
\text { Yield, } \%\end{array}$ & $\begin{array}{c}\text { Cold Carcass } \\
\text { Yield, \% }\end{array}$ & $\mathrm{RV} / \mathrm{TV}$ & $\begin{array}{l}\text { Breast Meat } \\
\text { Yield, \% }\end{array}$ & $\begin{array}{c}\text { Thigh Meat } \\
\text { Yield, \% }\end{array}$ \\
\hline SCP & $\begin{array}{l}\text { TN } \\
\text { HS }\end{array}$ & $\begin{array}{l}192 \\
192\end{array}$ & $\begin{array}{l}2.34 \\
2.30\end{array}$ & $\begin{array}{l}\mathrm{A} 1.11^{\mathrm{a}} \\
\mathrm{A} 1.12^{\mathrm{a}}\end{array}$ & $\begin{array}{l}\text { A73. } 0^{\mathrm{a}} \\
\mathrm{A} 70.6^{\mathrm{b}}\end{array}$ & $\begin{array}{l}\mathrm{A} 72.7^{\mathrm{a}} \\
\mathrm{A} 70.2^{\mathrm{b}}\end{array}$ & $\begin{array}{l}0.240 \\
0.243\end{array}$ & $\begin{array}{l}38.7 \\
38.6\end{array}$ & $\begin{array}{l}24.9 \\
25.3\end{array}$ \\
\hline $\mathrm{RCP}$ & $\begin{array}{l}\text { TN } \\
\text { HS }\end{array}$ & $\begin{array}{l}191 \\
189\end{array}$ & $\begin{array}{l}2.38 \\
2.25\end{array}$ & $\begin{array}{l}\text { A1.09a } \\
{ }^{\mathrm{B}} 1.00^{\mathrm{a}}\end{array}$ & $\begin{array}{l}{ }^{\mathrm{B}} 70.0^{\mathrm{a}} \\
{ }^{\mathrm{A}} 69.5^{\mathrm{a}}\end{array}$ & $\begin{array}{l}{ }^{\mathrm{B}} 69.7^{\mathrm{a}} \\
{ }^{\mathrm{A}} 69.2^{\mathrm{a}}\end{array}$ & $\begin{array}{l}0.249 \\
0.272\end{array}$ & $\begin{array}{l}38.4 \\
38.8\end{array}$ & $\begin{array}{l}25.0 \\
23.3\end{array}$ \\
\hline$R C P+T A 200$ & $\begin{array}{l}\text { TN } \\
\text { HS }\end{array}$ & $\begin{array}{l}192 \\
189\end{array}$ & $\begin{array}{l}2.47 \\
1.86\end{array}$ & $\begin{array}{l}{ }^{\mathrm{A}} 1.04^{\mathrm{a}} \\
\mathrm{C} 0.80^{\mathrm{b}}\end{array}$ & $\begin{array}{l}\text { A74. } 0^{\mathrm{a}} \\
{ }^{\mathrm{A}} 69.9^{\mathrm{b}}\end{array}$ & $\begin{array}{l}\text { A73. } 6^{\mathrm{a}} \\
\mathrm{A} 69.5^{\mathrm{b}}\end{array}$ & $\begin{array}{l}0.246 \\
0.252\end{array}$ & $\begin{array}{l}38.6 \\
38.3\end{array}$ & $\begin{array}{l}25.1 \\
24.5\end{array}$ \\
\hline RCP+PPE200 & $\begin{array}{l}\text { TN } \\
\text { HS }\end{array}$ & $\begin{array}{l}196 \\
186\end{array}$ & $\begin{array}{l}2.51 \\
1.92\end{array}$ & $\begin{array}{l}{ }^{\mathrm{A}} 1.12^{\mathrm{a}} \\
{ }^{\mathrm{C}} 0.77^{\mathrm{b}}\end{array}$ & $\begin{array}{l}{ }^{A} 72.1^{\mathrm{a}} \\
{ }^{\mathrm{A}} 69.0^{\mathrm{b}}\end{array}$ & $\begin{array}{l}{ }^{A} 71.8^{\mathrm{a}} \\
{ }^{\mathrm{A}} 68.7^{\mathrm{b}}\end{array}$ & $\begin{array}{l}0.246 \\
0.262\end{array}$ & $\begin{array}{l}38.3 \\
38.8\end{array}$ & $\begin{array}{l}24.3 \\
24.5\end{array}$ \\
\hline$R C P+A P E 200$ & $\begin{array}{l}\text { TN } \\
\text { HS }\end{array}$ & $\begin{array}{l}194 \\
185\end{array}$ & $\begin{array}{l}2.51 \\
1.99\end{array}$ & $\begin{array}{l}{ }^{\mathrm{A}} 1.04^{\mathrm{a}} \\
{ }^{\mathrm{B}} 0.98^{\mathrm{a}}\end{array}$ & $\begin{array}{l}{ }^{B} 71.1^{\mathrm{a}} \\
{ }^{\mathrm{A}} 68.6^{\mathrm{b}}\end{array}$ & $\begin{array}{l}{ }^{8} 70.8^{\mathrm{a}} \\
{ }^{\mathrm{A}} 68.3^{\mathrm{b}}\end{array}$ & $\begin{array}{l}0.250 \\
0.267\end{array}$ & $\begin{array}{l}38.3 \\
38.7\end{array}$ & $\begin{array}{l}24.8 \\
23.7\end{array}$ \\
\hline & $\begin{array}{c}\text { SCP } \\
\text { RCP } \\
\text { RCP+TA200 } \\
\text { RCP+PPE200 } \\
\text { RCP+APE200 }\end{array}$ & $\begin{array}{l}192 \\
190 \\
191 \\
191 \\
189\end{array}$ & $\begin{array}{l}2.32 \\
2.31 \\
2.16 \\
2.21 \\
2.25\end{array}$ & $\begin{array}{l}1.11 \\
1.05 \\
0.92 \\
0.94 \\
1.01\end{array}$ & $\begin{array}{l}71.8 \\
69.8 \\
71.9 \\
70.6 \\
69.9\end{array}$ & $\begin{array}{l}71.4 \\
69.4 \\
71.6 \\
70.2 \\
69.5\end{array}$ & $\begin{array}{l}0.241 \\
0.260 \\
0.249 \\
0.254 \\
0.259\end{array}$ & $\begin{array}{l}38.7 \\
38.6 \\
38.4 \\
38.6 \\
38.5\end{array}$ & $\begin{array}{l}25.1 \\
24.2 \\
24.8 \\
24.4 \\
24.2\end{array}$ \\
\hline SEM & & 1.500 & 0.111 & 0.055 & 0.354 & 0.352 & 0.007 & 0.362 & 0.238 \\
\hline TTS & $\begin{array}{l}\text { TN } \\
\text { HS }\end{array}$ & $\begin{array}{l}193 \\
188\end{array}$ & $\begin{array}{l}2.44^{\mathrm{a}} \\
2.06^{\mathrm{b}}\end{array}$ & $\begin{array}{l}1.08 \\
0.93\end{array}$ & $\begin{array}{l}72.1^{\mathrm{a}} \\
69.5^{\mathrm{b}}\end{array}$ & $\begin{array}{l}71.7^{\mathrm{a}} \\
69.2^{\mathrm{b}}\end{array}$ & $\begin{array}{l}0.246^{b} \\
0.259^{a}\end{array}$ & $\begin{array}{l}38.4 \\
38.6\end{array}$ & $\begin{array}{l}24.8 \\
24.3\end{array}$ \\
\hline SEM & & 0.949 & 0.070 & 0.035 & 0.224 & 0.223 & 0.004 & 0.229 & 0.150 \\
\hline$p$ value & & & & & & & & & \\
\hline $\begin{array}{l}\text { DTs } \\
\text { TTs } \\
\text { DTs } x \text { TTS }\end{array}$ & & $\begin{array}{l}\text { NS } \\
\text { NS } \\
\text { NS }\end{array}$ & $\begin{array}{l}\text { NS } \\
* \\
\text { NS }\end{array}$ & $\begin{array}{l}\text { NS } \\
\text { NS } \\
\star\end{array}$ & $\begin{array}{l}\text { NS } \\
* \\
*\end{array}$ & $\begin{array}{l}\text { NS } \\
* \\
*\end{array}$ & $\begin{array}{c}\text { NS } \\
* \\
\text { NS }\end{array}$ & $\begin{array}{l}\text { NS } \\
\text { NS } \\
\text { NS }\end{array}$ & $\begin{array}{l}\text { NS } \\
\text { NS } \\
\text { NS }\end{array}$ \\
\hline
\end{tabular}

${ }^{a-c}$ Values in the same column not sharing a common lowercase superscript indicate significant differences between temperature treatments $\left({ }^{*} p<0.05\right)$.

A-c Values in the same column not sharing a common uppercase superscript indicate significant differences among dietary treatments ( $\left.{ }^{*} p<0.05\right)$

DT: dietary treatments; TT: temperature treatments; ${ }^{1 T N}$ : thermoneutral temperature; ${ }^{2} \mathrm{HS}$ : heat stress. PSBW: preslaughter body weight; RT/TV: right ventricle weight to total ventricle weight ratio.

SCP: Diet with standard crude protein level (24\% crude protein, $2900 \mathrm{kcal}$ ME/kg); RCP: Reduced crude protein diet (21\% crude protein, $2900 \mathrm{kcal}$ ME/kg); RCP+TA200: RCP supplemented with $200 \mathrm{mg} \alpha$-tocopherol acetate/kg; RCP+PPE200: RCP supplemented with $200 \mathrm{mg}$ pomegranate peel extract/kg; RCP+APE200: RCP supplemented with 200 mg apple peel extract/kg to RCP diet

supplementation of an antioxidant to reduced-CP diet of broilers reduced the RV/TV ratio.

As indicated in Table 7, neither DTs nor TTS significantly influenced quail breast and thigh meat yields. These results are in agreement with the findings of Faria Filho et al. (2005) and Habibian et al. (2016), who showed that the breast and thigh meat yields of 49-day-old broilers were not affected by environmental temperature. On the other hand, Ain Baziz et al. (1996) and Azad et al. (2010) demonstrated that broilers chronically reared under HS presented a significant decrease in breast meat yield. Our results concur with the findings of Behrooj et al. (2012) and Sharifi et al. $(2015 a, b)$, who reported no significant breast and thigh meat yield differences between broilers fed a reduced $C P$ diet and a standard CP diet. In addition, Sharifi et al. (2015b) did not find any significant breast meat yield differences among broilers fed SCP, RCP and RCP+L-carnitine diets. Habibian et al. (2016) also reported that the breast meat yield of TN and heatstressed broilers was not influenced by vitamin $E$ supplementation.

\section{Malondialdehyde values of breast and thigh meat}

The effects of the experimental treatments on the malondialdehyde (MDA) values of the breast and thigh meats of quails are summarized in Table 8.

As indicated in Table 8, higher breast meat MDA values were determined in $\mathrm{HS}$ quails than those reared at TN both on days $0(p<0.01)$ and $7(p<0.05)$. This is in agreement with the results of Gu et al. (2008) and of Habibian et al. (2016), who reported that the MDA levels in the breast meat was significantly increased when broilers were submitted to HS. Oxidative stress is considered as part of the stress response of broilers to heat exposure. Birds are not able to eliminate the free radicals caused by HS from the body and the level of lipid oxidation is increased (Gu et al., 2008; Habibian et al., 2016). Aoyagi et al. (1997) found that broilers exposed to HS had lower antioxidant defense capacity and higher lipid peroxidation level and MDA values in the plasma and the liver. In the present study, the increase of MDA values in the breast meat of HS quails indicates cell damage by HS. 
Table 8 - The effects of experimental treatments on malondialdehyde values in the breast and thigh of quails reared under TN and HS conditions.

\begin{tabular}{|c|c|c|c|}
\hline \multirow{2}{*}{ DTs } & \multirow[t]{2}{*}{ TTS } & Day 0 & Day 7 \\
\hline & & Breast Thigh & Breast Thigh \\
\hline \multirow{2}{*}{$S C P$} & TN & 0.3560 .385 & 1.601 .50 \\
\hline & HS & 0.9241 .000 & 1.672 .20 \\
\hline \multirow{2}{*}{$\mathrm{RCP}$} & TN & 0.6350 .369 & 1.892 .48 \\
\hline & HS & 0.8801 .130 & 2.173 .11 \\
\hline \multirow{2}{*}{$R C P+T A 200$} & TN & 0.3120 .231 & 0.801 .19 \\
\hline & HS & 0.7050 .776 & 1.481 .46 \\
\hline \multirow{2}{*}{ RCP+PPE200 } & TN & 0.2650 .255 & 1.181 .13 \\
\hline & HS & 0.7160 .911 & 1.261 .46 \\
\hline \multirow{2}{*}{ RCP+APE200 } & TN & 0.2340 .364 & 1.581 .43 \\
\hline & HS & 0.7781 .080 & 2.082 .34 \\
\hline \multirow{5}{*}{ DTs } & SCP & $0.640^{b} 0.692^{b}$ & $1.64^{\mathrm{c}} 1.85^{\mathrm{b}}$ \\
\hline & $\mathrm{RCP}$ & $0.757^{a} 0.749^{a}$ & $2.03^{a} 2.79^{a}$ \\
\hline & $\mathrm{RCP}+\mathrm{TA} 200$ & $0.509^{c} 0.503^{d}$ & $1.14^{d} 1.32^{c}$ \\
\hline & RCP+PPE200 & $0.490^{c} 0.583^{c}$ & $1.22^{\mathrm{d}} 1.29^{c}$ \\
\hline & $R C P+A P E 200$ & $0.506^{c} 0.721^{a}$ & $1.83^{b} 1.89^{b}$ \\
\hline SEM & & 0.0740 .063 & 0.2000 .281 \\
\hline \multirow{2}{*}{ TTS } & $\mathrm{TN}^{1}$ & $0.360^{b} 0.321^{b}$ & $1.41^{b} 1.55^{b}$ \\
\hline & $\mathrm{HS}^{2}$ & $0.801^{a} 0.979^{a}$ & $1.73^{\mathrm{a}} 2.11^{\mathrm{a}}$ \\
\hline SEM & & 0.0470 .040 & 0.1270 .178 \\
\hline \multicolumn{4}{|l|}{$p$ value } \\
\hline DTs & & $\star \star$ & $\star \star \star *$ \\
\hline TTS & & $\star * \star *$ & $\star \star \star *$ \\
\hline DTs $x$ TTS & & NS NS & NS NS \\
\hline
\end{tabular}

${ }^{a-d}$ Values in the same column not sharing a common superscript significantly differ $\left({ }^{*} p<0.05\right)$.

DT: dietary treatments; $\mathrm{TT}$ : temperature treatments; ${ }^{1} \mathrm{TN}$ : thermoneutral temperature; ${ }^{2} \mathrm{HS}$ : heat stress.

SCP: Diet with standard crude protein level (24\% crude protein, $2900 \mathrm{kcal} \mathrm{ME} / \mathrm{kg}$ ); RCP: Reduced crude protein diet (21\% crude protein, $2900 \mathrm{kcal} \mathrm{ME} / \mathrm{kg}) ; \mathrm{RCP}+\mathrm{TA} 200$ : RCP supplemented with $200 \mathrm{mg} \alpha$-tocopherol acetate/kg; RCP+PPE200: RCP supplemented with $200 \mathrm{mg}$ pomegranate peel extract/kg; RCP+APE200: RCP supplemented with $200 \mathrm{mg}$ apple peel extract $/ \mathrm{kg}$.

The dietary treatments also significantly influenced breast meat MDA values both at 0 and 7 days of storage $(p<0.05)$. The lowest breast meat MDA values on day 0 were obtained when the RCP+TA200, RCP+PPE200 and RCP+APE200, and with the RCP+TA200 and $R C P+P P E 200$ diets on day 7 of storage $(p<0.05)$. These results are consistent with those of Habibian et al. (2016), who showed that the dietary supplementation of vitamin $\mathrm{E}$ reduced the level of lipid oxidation (MDA value) of the breast meat of broilers under HS, and with those of Saleh et al. $(2015,2017)$, who reported that dietary pomegranate peel extract significantly delayed the lipid oxidation of broiler meat. These findings may be attributed to polyphenolic compounds with the antioxidant activity present in PPE (Saleh et al., 2017), in addition to the synergism among phenolic compounds (Devatkal et al., 2010). These polyphenolic compounds enter the circulatory system, distributed, and retained in breast meat of broilers, where they remain functional (Saleh et al., 2017). The antioxidant activities of these polyphenols are a result of their ability to donate hydrogen molecules to block free radical chain reactions during the oxidation process, converting them into stable end products (Qin et al., 2013). In addition, polyphenols act as antioxidants by scavenging free radicals and binding metals, as well as to their reducing power (Naveena et al., 2008 a,b; Selani et al., 2011; Mahmmod 2014).

Higher thigh meat MDA values were detected in HS quails compared with those maintained at TN both on days $0(p<0.05)$ and $7(p<0.01)$ of storage. This finding does not agree with the results of Gu et al. (2008), who did not find any significant effect of HS on thigh meat MDA values of broilers. The lowest thigh meat MDA value on day 0 of storage was obtained in the quails fed the RCP+TA200 diet $(p<0.05)$, and on day 7 with the RCP+TA200 and RCP+PPE200 diets $(p<0.01)$.

\section{CONCLUSION}

In conclusion, pomegranate peel and apple peel extracts can be used as alternative natural antioxidant sources to vitamin $E$ in the diets of quails exposed to heat stress and fed a reduced crude protein diet, as shown by the growth performance, blood hematocrit and $\mathrm{H} / \mathrm{L}$ ratio, plasma uric acid level, liver catalase and glutathione peroxidase activities, and meat lipid peroxidation results.

\section{DISCLOSURE STATEMENT}

No potential conflict of interest is reported by the authors.

\section{FUNDING}

This project was supported by the authors.

\section{REFERENCES}

Abidin Z, Khatoon A. Heat stress in poultry and the beneficial effects of ascorbic acid (vitamin C) supplementation during periods of heat stress. World's Poultry Science Journal 2013;69(1):135-152.

Adams BM. Effect of cortisol on growth and uric acid excretion in the chick. Journal of Endocrinology 1968;40(2):145-151.

Aebi H. Catalase in vitro. In: Colowick SP, Kaplan NO, editors. Methods in enzymology. Orlando: Academic Press; 1984. v105, p.121-126.

Ahmed ST, Islam MM, Bostami AB, Mun HS, Kim YJ, Yang CJ. Meat composition, fatty acid profile and oxidative stability of meat from broilers supplemented with pomegranate (PunicagranatumL.) byproducts. Food Chemistry 2015;188:481-488. 
Ain Baziz H, Geraert PA, Padilha JCF, Guillaumin S. Chronic heat exposure enhances fat deposition and modifies muscle and fat partition in broiler carcasses. Poultry Science 1996;75:505-513.

Ajakaiye JJ, Perez-Bello A, Mollineda-Trujillo A. Impact of vitamins C and E dietary supplementation on leukocyte profile of layer hens exposed to high ambient temperature and humidity. Acta Veterinaria Brno 2010;79:377-383

AOAC. Association of Official Analytical Chemists. Official methods of analysis of AOAC international. 19th $\mathrm{ed}$. Gaithersburg; 2007.

Aoyagi Y, Ohnishi T, Itoh S. Effect of heat stress and L-ascorbic acid-2phosphate magnesium on plasma and liver thiobarbituric acid reactive substance concentration and on liver protein carbony concentration in chicks. Japanese Poultry Science 1997;34(1):63-66.

Avanzo JL, Juniorr CXM, Puginea SMP, Cesar MC. Effect of vitamin E and Selenium on resistance to oxidative stress in chicken superficial pectoralis muscle. Comparative Biochemistry and Physiology Part C 2001;129:163-173.

Aviram M, Dornfeld L, Rosenblat M, Volkova N, Kaplan M, et al. Pomegranate juice consumption reduces oxidative stress, atherogenic modifications to LDL, and platelet aggregation:studies in humans and in atherosclerotic apolipoprotein E-deficient mice. American Journal of Clinical Nutrition 2000;71:1062-76.

Ayazi M. Effect dietary glutamine and vitamin E supplementation on performance, some blood antioxidant indices in broiler chickens under contiuous heat stress temperature. International Journal of Farming and Allied Sciences 2014;3(12):1303-1310.

Aydilek N, Çadırcı S, Can A, Denek N, Çelik H, Kocagül S. Effect of free choice feeding as to protein levels on oxidative status in the broilers exposed to heat stress. Kafkas Üniversitesi Veteriner Fakültesi Dergisi 2012;18(6):1049-1054.

Azad MAK, Kikusato M, Maekawa T, Shirakawa H, Toyomizu M. Metabolic characteristics and oxidative damage to skeletal muscle in broiler chickens exposed to chronic heat stress. Comparative Biochemistry and Physiology Part A Molecular \& Integrative Physiology 2010;155:401406.

Behrooj N, Khajali F, Hassanpour H. Feeding reduced-protein diets to broilers subjected to hypobaric hypoxia is associated with the development of pulmonary hypertension syndrome. British Poultry Science 2012;53 (5):658-664.

Bonnet S, Geraert PA, Lessire M, Carre B, Guillaumin S. Effect of high ambient temperature on feed digestibility in broilers. Poultry Science 1997;76(6):857-863

Botsoglou NA, Florou-Paneri P, Christaki E, Fleouris DJ, Spais AB. Effects of dietary essential oil on performance of chickens and on iron-induced lipid oxidation of breast, thigh and abdominal fat tissues. British Poultry Science 2002;43:223-230.

Devatkal SK, Narsaiah K, Borah A. Anti-oxidant effect of extracts of kinnow rind, pomegranate rind and seed powders in cooked goat meat patties. Meat Science 2010;85:155-159.

Dkhil MA, Al-Quraishy S, Abdel Moneim AE. Effect of pomegranate (PunicagranatumL.) juice and methanolic peel extract on testis of male rats. Pakistan Journal of Zoology 2013;45(5):1343-1349.

Duncan DB. Multiple range test and multiple F tests. Biometrics 1955;11:142.

Elfalleh W, Hannachi H, Tlili N, Yahia Y, Nasri N, Ferchichi A. Total phenolic contents and antioxidant activities of pomegranate peel, seed, leaf and flower. Journal of Medicinal Plants Research 2012;6:4724-4730.
Faria Filho DE, Rosa PS, Vieira BS, Macari M, Furlan RL. Protein levels and environmental temperature effects on carcass characteristics, performance, and nitrogen excretion of broiler chickens from 7 to 21 days of age. Brazilian Journal Poultry Science 2005;7:247-253.

Faria Filho DE, Campos DMB, Alfonso-Torres KA, Vieira BS, Rosa PS, Vaz AM, Macar M, Furlan RL. Protein levels for heat-exposed broilers: performance, nutrients digestibility and energy and protein metabolism. International Journal Poultry Science 2007;6:187-194.

Furlan RL, Faria F, Rosa PS, Macari M. Does low-protein diet improve broiler performance under heat stress conditions. Brazilian Journal Poultry Science 2004;6(2):71-79.

Gazalli H, Malik AH, Sofi AH, Wan SA, Pal MA, Mir A, Ashraf H. Nutritional value and physiological effect of apple pomace. International Journal of Food Nutrition and Safety 2014;5(1):11-15.

Genena DM, Agamy NF. Effect of pomegranate juice and peel on antioxidant enzymes and lipid profile in carbon tetrachloride-induced hyperlipidemic rats. International Journal of Advanced Research 2017;5(1):1708-1714

Giomaro G, Karioti A, Bilia AR, Bucchini A, Giamperi L, Ricci D, Fraternale $D$. Polyphenols profile and antioxidant activity of skin and pulp of a rare apple from Marche region (Italy). Chemistry Central Journal 2014;1-10.

Gil MI, Tomas-Barberan FA, Hess-Pierce B, Holcroft DM, Kader AA. Antioxidant activity of pomegranate juice and its relationship with phenolic composition and processing. Journal of Agriculture and Food Chemistry 2000;48 (10):4581-4589.

Gonzalez-Esquerra R, Leeson S. Effects of acute versus chronic heat stress on broiler response to dietary protein. Poultry Science 2005;84:15621569 .

Gopi M, Purushothaman MR, Chandrasekaran D. Influence of coenzyme Q10 supplementation in high energy broiler diets on production performance, hematological and slaughter parameters under higher environmental temperature. Asian Journal of Animal and Veterinary Advances 2015;10(7):311-322.

Gross WB, Siegel HS. Evaluation of the heterophil/Lymphocyte ratio as a measure of stress in chickens. Avian Diseases 1983;27:972-979.

Gu XH, Li SS, Lin H. Effects of hot environment and dietary protein level on growth performance and meat quality of broiler chickens. AsianAustralasian Journal Animal Science 2008;21:1616-1623.

Habibian M, Ghazi S, MoeiniMM. Effects of dietary selenium and vitamin $\mathrm{E}$ on growth performance, meat yield and selenium content and lipid oxidation of breast meat of broilers reared under heat stress. Biological Trace Elements Research 2016;169(1):142-152.

Hai L, Rong D, Zhang ZY. The effect of thermal environment on the digestion of broilers. Journal of Animal Physiology and Animal Nutrition 2000;83:57-64.

Halici M, Imik $H$, Koç M, Gümü $\square$ R. Effects of $\alpha$-lipoic acid, vitamins $E$ and $C$ upon the heat stress in Japanese quails. Journal of Animal Physiology and Animal Nutrition 2012;96(3):408-415.

Hayes JE, Allen P, Brunton N, O'Grady MN, Kerry JP. Phenolic composition and in vitro antioxidant capacity of four commercial phytochemical products:olive leaf extract (oleaeuropaea L.) lutein, sesamol and ellagic acid. Food Chemistry 2011;126:948-955.

Imik H, Kaynar O, Ozkanlar S, Gumu $\square$ R, Polat H, Ozkanlar Y. Effects of vitamin $C$ and $\alpha$-lipoid acid dietary supplementations on metabolic adaptation of broilers to heat stress. Revue de Médecine Vétérinaire 2013;164(2):52-59. 
Ipek H, Avcı M, Yerturk M, Iriadam M, Aydilek N. Effects of ascorbic acid and vitamin $E$ on performance and hematological parameters of Japanese quails under high ambient temperature in Sanliurfa. Arch fuer Gefluegelkund 2007;71(3):130-134

Ismail IB, Al-Busadah KA, El-Bahr SM. Biochemical markers of oxidative stress in tissues of broiler chickens fed zinc bacitracin and ascorbic acid under hot climate. International Journal of Biological and Chemical Sciences 2015;9(1):38-45

Jena BP, Panda N, Patra RC, Mishra PK, Behura NC, Panigrahi B. Supplementation of vitamin $E$ and $C$ reduces oxidative stress in broiler breeder hens during summer. Food and Nutrition Science 2013;4:3337.

Kamboh AA, Zhu WY. Effect of increasing levels of bioflavonoids in broiler feed on plasma anti-oxidative potential, lipid metabolites and fatty acid composition of meat. Poultry Science 2013;92:454-461.

Kanatt SR, Chander R, Sharma A. Antioxidant and antimicrobial activity of pomegranate peel extract improves the shelf life of chicken products. International Journal of Food Science and Technology 2010;45:216222.

Konca Y, Kirkpinar F, Çabuk M. Effects of dietary ascorbic acid on blood haematological profile, serum biochemical components and tonic immobility reaction of male turkeys under summer condition. Journal Poultry Science 2009;46:105-111.

Lara LJ, Rostagno $\mathrm{MH}$. Impact of heat stress on poultry production. Animal 2013;3(2):356-369.

Leccese A, Bartolini S, Viti R. Antioxidant properties of peel and flesh in 'GoldRush' and 'Fiorina' Scab-resistant apple (Malus domestica) cultivars. New Zealand Journal of Crop and Horticulture Science 2009;37:71-78

Li Y, Guo C, Yang J, Wei J, Xu J, Cheng S. Evaluation of antioxidant properties of pomegranate peel extract in comparison with pomegranate pulp extract. Food Chemistry 2006;96(2):254-260.

Lowry OH, Rosenbrough NJ, Farr AL, Randall RJ. Protein measurement with the folin phenol reagent. Journal of Biological Chemistry 1951;193:265-275

Mahmmod AB. Study the effects of olive leaf extarct on physio-chemical and sensory traits of mutton meat at low temperature. Assiut Veterinary Medical Journal 2014;60(143):1-7.

Malviya S, Arvind AJ, Hettiarachchy N. Antioxidant and antibacterial potential of pomegranate extracts. Journal Food Science and Technology 2014;51(12):4132-4137.

Moneim AE. Evaluating the potential role of pomegranate peel in aluminum-induced oxidative stress and histopathological alterations in brain of female rats. Biological Trace Element Research 2012;150(13):328-336

Naveena BM, Sen AR, Vaithiyanathan S, Babji Y, Kondaiah N. Comparative efficacy of pomegranate juice, pomegranate rind powder extract and BHT as antioxidants in cooked chicken patties. Meat Science 2008a;80(4):1304-1308

Naveena BM, Sen AR, Kingsly RP, Singh DB, Kondaiah N. Antioxidant activity of pomegranate rind powder extract in cooked chicken patties. International Journal of Food Science and Technology 2008b;43(10):1807-1812.

Nieto R, Aguilera JF, Fernandez-Figares I, Prieto C. Effect of a low protein diet on the energy metabolism of growing chickens. Arch Tierernahr1997; 50:105-109.
Noyan A. Physiology. Ankara: Meteksan Anonym Company; 1993.

NRC - Nutrient Requirements of Domestic Animals. Nutrient requirements of poultry. $9^{\text {th }}$ ed. Washington: National Academic Press; 1994.

Qin YY, Zhang ZH, Li L, Xiong W, Shi JY, Zhao TR, et al. Antioxidant effect of pomegaranate rind powder extract, pomegranate juice, and pomegranate seed powder extract as antioxidants in raw ground pork meat. Food Science Biotechnology 2013;22(4):1063-1069.

Paglia DE, Valentine WN. Studies on the quantitative and qualitative characterisation of erythrocyte glutathione peroxidase. Journal of Laboratory and Clinical Medicine 1967;70:158-169.

Prieto MT, Campo JL. Effect of heat and several additives related to stress levels on fluctuating asymmetry, heterophil:lymphocyte ratio, and tonic immobility duration in white Leghorn chicks. Poultry Science 2010:89:2071-2077.

Rhoads RP, Baumgard LH, Suagee JK, Sanders SR. Nutritional interventions to alleviate the negative consequences of heat stress. Advances Nutritionm 2013:4:267-276.

Rupasinghe HP, Kean C V. Polyphenol concentrations in apple processing byproducts determined using electrospray ionization massspectrometry. Canadian Journal of Plant Science 2008;88:759-762.

Sahin $\mathrm{K}$, Kucuk O. Effects of vitamin $\mathrm{C}$ and vitamin $\mathrm{E}$ on performance, digestion of nutrients and carcass characteristics of Japanese quails reared under chronic heat stress. Journal of Animal Physiology and Animal Nutrition 2001;85:335-341.

Sahin K, Kucuk O, Sahin N, Gursu MF. Optimal dietary concentration of vitamin $\mathrm{E}$ for alleviating the effect of heat stress on performance, tyroid status, ACTH and some serum metabolite and mineral concentrations in broilers. Veterinarni medicina Czech 2002;47(4):110-116.

Sahin K, Sahin N, Kucuk O, Hayirli A, Prasad AS. Role of dieatary zinc in heat-stressed poultry: a review. Poultry Science 2009;88:2176-2183

Sahin K, Orhan C, Smith MO, Sahin N. Molecular targets of dietary phytochemicals for the alleviation of heat stress in poultry. World's Poultry Science Journal 2013;69(1):113-123

Saleh H, Golian A, Kermanshahi H, Farhosh R, Abrishamchi R. Evaluation of $\alpha$-tocopherol actetate, peel and extarctpomegrante antioxidative potential in diet contained fish oil on meat quality broiler chickens. Iranian Journal of Animal Science Research 2015;7(3):305-317.

Saleh H, Golian A, Kermanshahi H, Mirakzchi MT. Effects of dietary $\alpha$-tocopherol acetate, pomegranate peel and pomegranate peel extract on phenolic content, fatty aid composition and meat quality of broiler chickens. Journal of Applied Animal Research 2017;45(1):629-636.

Sekhon-Loodu S, Warnakulasuriya SN, Rupasinghe HPV, Shahidi F. Antioxidant ability of fractionated apple peel phenolics to inhibit fish oil oxidation. Food Chemistry 2013;140:189-196.

Selani MM, Conteras-Castillo CJ, Shirahigue LD, Gallo CR, Plata-Ovicdo $\mathrm{M}$, Montes-Villanveva ND. Wine industry residues extracts as natura antioxidants in raw and cooked chicken meat during frozen storage. Meat Science 2011;88:397-403.

Shabtay A, Eitam H, Tadmor Y, Orlov A, Meir A, Weinberg P, Weinberg ZG, Chen Y, Brosh A, Izhaki I, Kerem Z. Nutritive and antioxidative potential of fresh and stored pomegranate industrial by product as a novel beef cattle feed. Journal of Agricultural Food Chemistry 2008;56:1006310070.

Sharifi MR, Hassanpour H, Khajali F. Dietary L-carnitine supplement sounteracts pulmonary hypertensive response in broiler chickens fed reduced-protein diets and subjected to cool condition and hypobaric hypoxia. Journal Poultry Science 2015a;52:206-212. 
Sharifi MR, KhajaliF, Hassanpour H, Pour-Reza J, Pirany N. L-arginine supplementation of reduced-protein diets improves pulmonary hypertensive response in broiler chickens reared at high altitude. British Poultry Science 2015b;56(4):470-476.

Sharifi MR, Khajali F, Hassanpour H. Antioxidant supplementation of lowprotein diets reduced susceptibility to pulmonary hypertension in broiler chickens raised at high altitude. Journal of Animal Physiology and Animal Nutrition 2016;100 (1):69-76.

Siegel HS, Van Kampen M. Energy relationships in growing chickens given daily injections of corticosterone. British Poultry Science 1984;25:477485.

Singh RP, Chidambara-Murthy KN, Jayaprakasha GK. Studies on the antioxidant activity of pomegranate (Punicagranatum) peel and seed extracts using in vitro models. Journal of Agricultural Food Chemistry 2002;50 (1):81-86.

SPSSWIN 2007. Release 6.1. Copyright (c) SPSS; 1989-1994.

Sumathy R, Sankaranarayanan S, Bama P, Ramachandran J, Vijayalakshmi M, Deecaraman M. Antioxidant and antihemolytic activity of flavanoid extract from fruit peel of punicagranatum. Asian Journal of Pharmaceutical and Clinical Research 2013;6(2):211-214.

Sun Y, Oberley LW, Ying L. A simple method for clinical assay of superoxide dismutase. Clinical Chemistry 1988;34:497-500

Tawfeek SS, Hassanin KMA, Youssef IMI. The effect of dietary supplementation of some antioxidants on performance, oxidative stress and blood parametres in broilers under natural summer conditions. Journal World's Poultry Research 2014;4(1):10-19.

Temim S, Chagneau AM, Guillaumin S, Michel J, Peres-Son R, Geraert PA, et al. Effects of chronic heat exposure and protein intake on growth performance, nitrogen retention and muscle development in broiler chickens. Reproduction Nutrition Development 1999;39:145-156.

Temim S, Chagneau AM, Guillaumin S, Michel J, Peresson R, Tesseraud $S$. Does excess dietary protein improve growth performance and carcass characteristics in heat-exposed chickens? Poultry Science 2000;79(3):312-317.

Wang X, Li C, Liang D, Zou Y, Li P, Ma F. Phenolic compounds and antioxidant activity in red-fleshed apples. Journal of Functional Foods 2014;1-9.

Wei XL, Fang RT, Yang YH, Bi XY, Ren GX, Luo $A L$, et al. Protective effects of extracts from pomegranate peels and seeds on liver fibrosis induced by carbon tetrachloride in rats. BMC Complementary And Alternative Medicine 2015;15:389-398.

Widyaratne GP, Drew MD. Effects of protein level and digestibility on the growth and carcass characteristics of broiler chickens. Poultry Science 2011;90:595-603

Wolfe K, Wu X, Liv RH. Antioxidant activity of apple peels. Journal of Agricultural Food Chemistry 2003;51:609-614.

WPSA. European table of energy values for poultry feedstuffs. $3^{\text {rd }}$ ed. Beekbergen: WPSA Subcommittee; 1989

Yang L, Tan GY, Fu YQ, Feng JH, Zhang MH. Effects of acute heat stress and subsequent stress removal on function of hepatic mitochondrial respiration, ROS production and lipid peroxidation in broiler chickens. Comparative Biochemistry and Physiology Part C 2010;151:204-208.

Yassein DMM, Abdallah EA, Ismail II, Faddle AA. Effect of dietary supplementation of pomegranate peel powder and butylated hydroxy toluene on some productive, physiological and immunological parameters of japanese quail. Egyptian Journal Animal Production 2015; $52: 105-113$

Zaki SA, Abdelatif SH, Abdelmohsen NR, Ismail FA. Phenolic compounds and antioxidant activities of pomegranate peels. International Journal of Food Engineering 2015;1(2):73-76.

Zuprizal M, Larbiel A, Chagneau M, Geraert PA. Influence of ambient temperature of true digestibility of protein and amino acids of rapeseed and soybean meal in broilers. Poultry Science 1993;72:289-295. 